\title{
Padovská konference o italském slavistovi Arturu Croniovi
}

\author{
Miloš Zelenka (České Budějovice)
}

Ve dnech 20.-21. 11. 2017 se na staroslavné Univerzitě v Padově, která byla založena v roce 1222 a která je považována s Bolognou za nejstarší vysokoškolské instituce na světě, konala mezinárodní konference pod názvem Arturo Cronia. L'eredità di un Maestro a cinquant'anni dalla scomparsa věnovaná životu a dílu slavisty a literárního historika Artura Cronii (1896-1967). Vzorně připravené setkání, na němž má největší zásluhu současná vedoucí padovské slavistiky Rosanna Benacchio se svou asistentkou Monikou Fin, pořádal Dipartimento di studi lingustici e letterari (DISLL) ve spolupráci se Společností věd a umění Academia Galileiana u příležitosti 50. výročí úmrtí italského filologa působícího v letech 1929-1936 na Masarykově univerzitě v Brně, na Karlově univerzitě v Praze a částečně i na Univerzitě Komenského v Bratislavě v meziválečném Československu. Cronia svou vědeckou činností, dále i výchovou překladatelů a celé řady romanistů, položil základy české italistiky. Jako první italský slavista získal roku 1924 docenturu ze serbokroatistiky - nepochybně zde svou roli sehrálo místo narození v chorvatském Zadaru. Vyhraněná badatelská osobnost širokého tematického a časového záběru, který sahal od Cyrila a Metoděje až po současné písemnictví, od tvorby gramatik až po syntetické monografie, chápala slovanskou filologii jako organickou jednotu jazyka a literatury, přičemž univerzálností metod se zařazovala po bok velkých evropských slavistů 20. století. Zároveň Cronia svou mnohostrannou propagací slovanské kultury v italském prostředí navázal na nejlepší tradice domácí slavistiky reprezentované v meziválečném období jmény jako G. Maver, E. Lo Gatto, W. Giusti, E. Damiani ad. $\mathrm{K}$ badatelovým metodologickým zásadám patřily kriticismus, objektivita, faktografická přesnost a smysl pro rozvoj národních filologií, který se odrazil v zájmu o malé slovanské kultury. V jejich propagaci a vědeckém zkoumání badatel viděl - stejně jako v př́ípadě italštiny - nejvhodnější prostředek pro upevňování vlasteneckého vědomí. Tato orientace jej sbližovala s první zakladatelskou generací české slavistiky a komparatistiky, jako byl J. Máchal, M. Murko a zejména J. Polívka, u něhož Cronia již počátkem dvacátých let absolvoval postgraduální studium jako stipendista na FF UK v Praze po první světové válce.

Dvoudenní konferenci, jejíž zahájení proběhlo v překrásném historickém sálu Guarento Academiae Galileiana, po pozdravech rektora padovské univerzity Rosaria Rizzutiho, prezidenta Academiae Galileiana Carla Giacoma Somedy a předsedy Italského komitétu slavistů Giorgia Ziffera, uvedl referát Rossany Benacchio (Padova), který podrobně prezentoval biografii a vývojové kontury Croniova rozsáhlého díla spjatého převážně s Padovou. Zatímco Marcello Garzaniti (Firenze) ukázal na badatelovu všestrannou filologickou a kulturněhistorickou znalost slovanského světa v monografii $L a$ conoscenca del mondo slavo in Italia (1958) jako jistého hodnotového mezníku ve vývoji italské slavistiky, Barbara Lomagistro (Bari) se věnovala otázce původnosti dalmatského hlaholismu, kterou Cronia nastínil ve spise L'enigma del glagolismo in Dalmatia dalle origini all epoca presente (1922). Na tento referát navázala Valnea del Bianco (Pula), která přiblížila Croniův vztah k chorvatskému písemnictví, na které zejména v renesanční době působily italské vlivy. První den rokování uzavřelo vystoupení Rosanny Morabiti (Neapol) zabývající se badatelovou interpretací chorvatského básníka a dramatika Marina Držiće (v italštině Marino Darsa).

Následující jednání, které se přeneslo do historického sálu (Archivio antica) univerzitní knihovny padovské univerzity, zahájila Zlata Bojović (Bělehrad), která charakterizovala vědeckou korespondenci mezi dubrovnickým sběratelem lidové slovesnosti Petarem Kolendićem a Arturem Croniou. Maria Rita Leto 
(Pescara) poté rekapitulovala genezi a ohlas srbochorvatské lidové poezie $\mathrm{v}$ badatelově antologii La poesia popolare serbo-croata (1941). Mirka Zogović (Bělehrad) analyzovala Croniovy příručky a přehledové práce věnované klíčovým problémům teorie a dějin slovanské filologie, přičemž stejně jako italský slavista Garzaniti vyzdvihla bilanční monografii La conoscenca del mondo slavo in Italia. Na badatelovy práce mapující recepční ohlas Danteho a Petrarky v západoslovanských a jihoslovanských literaturách se zaměřil Guido Baldassarri (Padova). Autor těchto řádků (Praha - České Budějovice), který byl jediným zástupcem středoevropské slavistiky, v italsky předneseném referátu, na základě neznámého archivního materiálu, interpretoval autorovy bohemistické texty vzniklé v meziválečném Československu v souvislosti s jeho metodologickou pozicí spojující kriticismus německé pozitivistické filologie s croceovským, esteticko-psychologizujícím vcítěním. V návaznosti na tuto tematiku Croniova bohemistická studia po roce 1945 doplnil př́spěvek Alessandra Catalana (Padova). Zatímco Monica Fin (Padova) vymezila badatelův koncepční a organizační podíl na budování slavistické knihovny na padovské univerzitě, Han Steenwijk (Padova) podal lingvistickou analýzu trojjazyčného slovníku chorvatského kanovníka ze Zadaru Ivana Tanzlinghera Zanottiho (Vocabolario di tre nobilissimi linguaggi, italiano, illirico e latino), digitalizovaného péčí tamních slavistů - referenta a Rosanny Benacchio. Konferenci posléze uzavřel kulturněhistoricky koncipovaný referát Egidia Ivetiće (Padova), reflektující badatelovu zprostředkovatelskou úlohu propagátora kulturních styků mezi Adriatikem a Balkánem.

Konference, která byla symbolickým výrazem uznání nejen padovské slavistiky, ale obecně italské filologie mnohostrannému Croniovu vědeckému, pedagogickému i organizátorskému dílu, potvrdila jeho zakladatelský význam v kulturních dějinách slovansko - neslovanských vztahů. Badatelova bibliografie, čítající slovníky, gramatiky, monografie, recenze, antologie a edice, dosahuje stovky položek, mezi nimiž vynikají práce z binární komparatistiky dokumentující ohlas italské kultury v západoslovanských a jihoslovanských literaturách. Cronia, jako řádný profesor slovanské filologie na padovské univerzitě, patří i do dějin české slavistiky a bohemistiky, jejíž tematické horizonty rozšíríil dodnes faktograficky cennou, česky vydanou monografií Čechy v dějinách italské kultury. Tisíciletá žeň (1936), která podle badatelova skromného vyjádření jen shrnula vše „co kdy Italové vědèli a napsali o Čechách“.

\section{prof. PhDr. Miloš Zelenka, DrSc.}

Katedra slovanských jazyků a literatur

Pedagogická fakulta, Jihočeská univerzita

Jeronýmova 10, 37115 České Budějovice, Česká republika

zelenka@pf.jcu.cz 